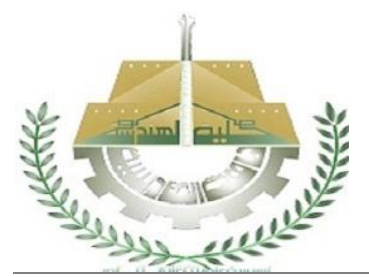

\title{
STUDYING THE EVALUATION OF THE EFFICIENCY OF PHOSPHORIC ACID ON THE SEPARATION OF NICKEL FROM THE WASTE OF SOUTH BAGHDAD THERMAL POWER STATION
}

\author{
Basheer Hashem Hlihl, \\ Middle Technical University, Institute of technology-Baghdad \\ E mail: bashhash66@gmail.com
}

\begin{abstract}
The process of separating nickel from the waste of thermal power stations has a positive effect on the environment and has a good economic return. . In this study, nickel was separated from the wastes of the South Baghdad thermal power station by using phosphoric acid. The investigation studied the influence parameters ( concentration of acid, temperature, time, size of waste granules and acid to the waste quantity ratio) on separation process of nickel. The best conditions in the separation process were obtained when the concentration of acid is 5 molarities, the temperature $50^{\circ} \mathrm{C}$, the duration time of separation is 4 hours, the acid phosphoric to the waste quantity ratio is 30 , and the size of the waste granules is $150 \mu \mathrm{m}$. The percentage of nickel that can be separated from the wastes of south Baghdad thermal power station reaches $81 \%$.
\end{abstract}

Keywords: south Baghdad thermal power station, nickel separating, evaluation of the phosphoric acid

\section{INTRODUCTION}

Nickel is considered a rare element in the soil because its concentration does not exceed $56 \mathrm{mg} / \mathrm{Kg}$, its rating 22 in terms of abundance of elements in the crust of earth( أ.د.نور الدين و أ.د.شفيق، 2012) . Nickel has many important uses, especially in the chemical, steel, paint, money alloyed, computer, jewelry, printing, catalysts, and electrical industries. Approximately 700,000 tons of nickel are consumed annually (Cunningham et al., 2007). In spite of the importance of nickel in many industrial fields, but itis classified as heavy metal which leads to cancer due to concentration increasing in the soil and then in the food chain for human and animals, (د. السعدي،2008). About one-third of the amount of nickel used in the industry comes from the recycling of industrial wastes, including the remnants of thermal power stations which contain a number of important elements such as nickel, vanadium, cobalt, cadmium, aluminum and others, the separation of these elements from the remnants of thermal power plants reduces areas used in landfill of these wastes and on the other hand these elements are of economic value(Cunningham et al., 2007). Several previous studies have investigated the removal of nickel from fly ash. Sulfuric acid was used to separate nickel from residual solution after the separation of vanadium and molybdenum from fly ash. Soluble nickel treatment with sodium carbonate was used to obtain nickel carbonate in the form of precipitation. The extracted nickel ratio was $85 \%$ by weight (Stas et al.,2007). Nitric acid was used to extract nickel from fly ash and the extraction ratio for nickel was $80 \%$ by weight. Nitric acid was found to be more efficient than sulfuric acid when comparing the results of that study (Mousa et al., 2011) with another results search (Ashraf,2000). Ammonium hydroxide was used as adsorption substance to extraction nickel from fly ash. The study shows that increasing of the mixing speed of the mixture and temperature increases the ratio of nickel separation. This study also showed that the dominate step of the reaction is the liquid layer surrounding the particles of fly ash (Mousa et al.,2012). The electrostatic deposition method was used to extract the adsorbed nickel from fly ash after being treated with sulfuric acid. The extracted nickel was 75\% from nickel weight in fly ash and purity was 97.83\% (أ.د عماد أيوب يوسف و اخرون، 2007).

Page 197 Copyright (c) 2018 Al-Qadisiyah Journal For Enginnering Science. All rights reserved. 
Nickel was separated from catalysts, which were found to contain $8.15 \%$ of dry weight. Sulfuric acid was used in the separation process and was found better than nitric acid and hydrochloric acid when the pH of the solution was adjusted to 9.92 using sodium hydroxide. The separated nickel was $80 \%$ weight of nickel in catalysts (Othman \& Yulisman,1999). The modified Akita method was used to separate nickel by using ammonium hydroxide and deposition by sodium sulfate. The ratio of nickel to vanadium was $27 \%$ and then vanadium was separated using sodium carbonate and precipitated by ammonium chloride. The ratio of vanadium to nickel was $55 \%$ (Al-Ghouti et al.,2011).Nickel was separated from fly ash by sodium carbonate and ammonium chloride. The nickel ratio in the solution was $91 \%$ after that nickel was deposed by sodium sulfate with $99.9 \%$ efficiency and purity of $99 \%$ (Abu Zaid,2010). Fly ash was found to be a good adsorbed material for nickel in contaminated water, especially in low concentration after being treated with sodium hydroxide (Visa \& Duta,2008). Nickel and other heavy metals beyond chromium and cadmium converting them with silicon, calcium, aluminum and iron oxide to material of a glass nature that have little harmful effect on the environment and lesser size, which leads to reduce the area used for landfill fly ash (Sobiecka \& Sroczynski,2011). The aim of this research is to study the possibility of separating nickel from fly ash using phosphoric acid and determining the best condition for nickel separation.

\section{PRACTICAL WORK}

The fly ash was obtained from the south Baghdad thermal power station, where it was classified into several sections of particles with different diameters ranging from (150-1000 micrometers) by the vibrator sieve apparatus. Phosphoric acid (Riedel-de Haen company) was used as adsorption substance. A number of phosphoric acid solution with different concentration were prepared (2-10 molarities).A quantity of fly ash and phosphoric acid was placed in a glass flask with capacity of 0.5 liter and mixed by magnetic stirrer for different period of time ranging from ( 1 to 5 hours). After that, the solution was filtered with paper filter and yellowish green solution was obtained. The concentration of nickel and heavy metals in fly ash (shown in table 1) was determined by XEPOS atomic spectrometer device in the Ministry of Science and Technology- Material Research Center. The effect of particle diameter, duration time, concentration of phosphoric acid, temperature of solution and the ratio of acid to fly ash were studied.

\section{DISCUSSION OF RESULTS}

The effect of phosphoric acid concentration on the separation of nickel from fly ash is shown in Fig. (1). It was found that the separation of nickel ratio rises from $21 \%$ at 2 molarities to $50 \%$ at 5 molarities and noticed the increase of concentration of acid above 5 molarities had been accompanied by a small increase in the ratio of nickel separation. At 10 molarities of acid, the ratio of nickel separation equals $55 \%$. The increase of the concentration of phosphoric acid is accompanied by an increase in the hydrogen ions in the solution, which increases the probability of exchange with the nickel oxide formed water and release the nickel in the solution. This result has been obtained in previous studies (Stas et al., 2007),(Othman \& Yulisman,1999) and (أ.د عماد أيوب يوسف و اخرون 2007). Figure (1) shows that the best concentration of phosphoric acid is 5 molarities, with a nickel separation ratio equals $50 \%$.

To illustrate the effect of temperature on the separation of nickel from fly ash, a number of experiments were done with temperature ranging from $(25 \text { to } 90)^{\circ} \mathrm{C}$. The results show increase separation ratio of nickel between $(25 \text { to } 50)^{\circ} \mathrm{C}$ is $(50 \%$ , $58 \%$ ) respectively. When the temperature exceeds $50^{\circ} \mathrm{C}$, the increase in the nickel separation ratio is very low. The increasing in temperature will increase the kinetic energy of hydrogen ions and increase the ability of hydrogen ions to remove the nickel from fly ash. It was found that the best degree of temperature to remove nickel is up to $50^{\circ} \mathrm{C}$ where the nickel separation ratio is $58 \%$. This result is shown in Figure (2) and this result has been obtained in previous studies (Stas et al., 2007) and (أ.د عماد أيوب يوسف و اخرون).

The effect of duration time on the process of separating nickel from fly dust by phosphoric acid was illustrated by Figure(3).It was observed that the separation ratio of nickel will increase from $39 \%$ to $78 \%$ when the time is increased from 1 to 4 hours. After this time the increase of the separation ratio of nickel is very low. This is because the increase of time gives the opportunity to release hydrogen ions from the phosphoric acid in the solution and react with the nickel compounds in the fly ash. After this time, the efficiency of adsorption is reduced because the hydrogen ions adsorption of most nickel oxide sites near the surface of the fly ash and only the deep sites remain in the pores contain the nickel oxide therefore the hydrogen ions need a longer time to reach the deep sites and these results were agreed with previous studies (Stas et al.,2007),(Mousa et al., 2011) and (أ.د عمادو اخرون، 2007). From the previous results it was shown that the best period for nickel separation from waste is (4) hours, which the separation of nickel ratio was $78 \%$. 


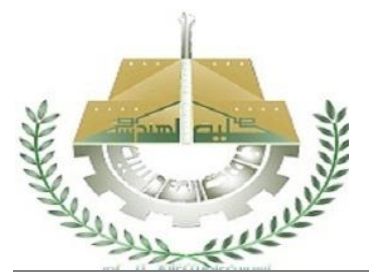

The ratio of phosphoric acid to fly ash was studies as shown in Figure (4). It was found that the increasing of the ratio of acid to fly ash from (10-50) increases the separation ratio of nickel from (50\%-89\%) due to increase of hydrogen ions in the solution. The best ratio of acid to fly ash was found to be 30 , where the nickel separation ratio is $81 \%$. After that, the increase in the ratio of acid to fly ash accompanied by slight increase in the ratio of nickel separated. These results were agreed with studies of (Stas et al.,2007) and (أ.د عماد و اخرون، 2007).

The effect of fly ash particle size on nickel separation ratio is shown in Figure (5). Small particles were found to be better than large particles of fly ash in the nickel separation process .The results of nickel separation ratio is $(13,31,50) \%$ for particles with diameters $(1000-500,500-150,<150) \mu \mathrm{m}$ respectively. This is due to the fact, that small particles has large surface area, which will react with hydrogen ions released from phosphoric acid easily and increase the adsorption efficiency of nickel.

\section{CONCLUSION}

The percentage of nickel in fly ash, which is a waste of south Baghdad thermal power station was found $0.1779 \%$ of total weight. The experiment showed the increase of phosphoric acid, temperature of solution, separated time and phosphoric acid to fly ash quantity the nickel separated was increased and the nickel separated increase when the diameter of particles were decreased. The nickel separation efficiency is $81 \%$ at phosphoric acid concentration 5 molarities, solution temperature $50{ }^{\circ} \mathrm{C}$, duration time 4 hours, phosphoric acid to fly ash equal 30 and diameter of particles less than $150 \mu \mathrm{m}$

\section{REFRENCES}

1. Abu zaid, A.H.M., (2010), " Selective Recovery of Vanadium and Nickel from Heavy Oil Fly Ash" Isotpic \& Rad. Res., 42(3), pp 659-668

2.Al- Ghouti, A., M., Al-Degs, Y.,S., Hani, K., Ziedan M., (2011), " Extraction and Separation of Vanadium and Nickel from Fly Ash produced in Heavy Fuel Power Plants "Chemical Engineering Journal " 173 pp 191-197

3. Amer Ashraf ,(2000) " Processing of Egyptian Boiler-ash for Extraction of Vanadium and Nickel" Physicochemical problems of Mineral Processing, V34,pp 153-161

4. Cunningham, P.W., Cunningham,A.,M.,Saigo,B.,W.,2007, Environmental Science: A Global Concern, ninth edition, Published by McGraw-Hill Companies, pag. 306-307,401,485

5. Mousa, K.,M., Al-saady, F.,A., Mahmood, E., M., (2011), " Nickel Recovery from Residue of Heavy Oil Using Nitric Acid", Journal of Petroleum Research \& Studies, No.3,pp.87-94

6. Mousa, K.,M., M.Ali, Sh., I., Hadi, H., (2012),"Extraction of Nickel From Fly Ash of Heavy Oil Using Ammonium Hydroxide ", Al- Qadisiya Journal For Engineering Sciences, Vol.5,No.1,pp.3843

7. Othman, H.B. Mat. \& Yuliusman, (1999)," Selective Nickel Recovery From Spent Catalyst". World Engineering Congress and Exhibition(WEC99);Kuala Lampur, July 19-22

8. Sobiecka, E., \& Sroczynski, W.,(2011) " Fly ash vitrification as the effective physico-chemical waste stabilization method" Biotechnology and Food Science 75 (2),35-38 
9. Stas, J., Dahdouh, A., Al-chayah, O., (2007)," Recovery of vanadium, nickel and molybdenum from fly ash of heavy oil-fired electrical power station", Chemical Engineering, 51/2,67-70,Syria.

10. Visa, M., \& Duta, A., (2008) " Cadmium and Nickel Removal From Waste Water Using Modified Fly Ash: Thermodynamic Study" Scintific Study\& Research Vol. IX(1) pp 73-82

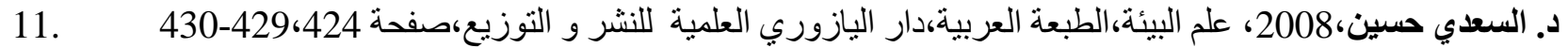

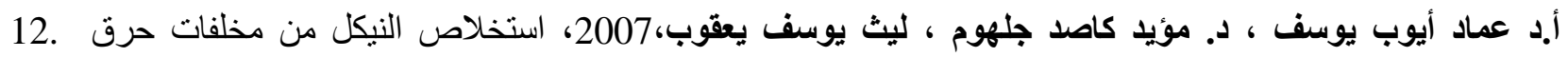
الوقود الثقيل بالإذابة المائية و ترسب فلزه كهربائيا، مجلة الهندسة و التكنولوجيا،المجلد 25،ملحق العدد3، صفحة 143-158 من الئل

أ.د. نور الدين شوقي علي ,أ.د. شفيق جلاب سالم،2012، كيمياء التربة،الطبعة المترجمة،دار الكتب العلمية للطباعة و النشر.13 و التوزيع،صفحة الدين 4

Table (1): Concentration of some important elements in the fly dust from south Baghdad thermal power station

\begin{tabular}{|l|l|l|l|l|l|l|}
\hline Element & Vanadium & Chromium & Iron & Cobalt & Nickel & Molybdenum \\
\hline Concentration(wt\%) & 0.6817 & 0.0260 & 10.01 & 0.003 & 0.1779 & 0.0272 \\
\hline
\end{tabular}

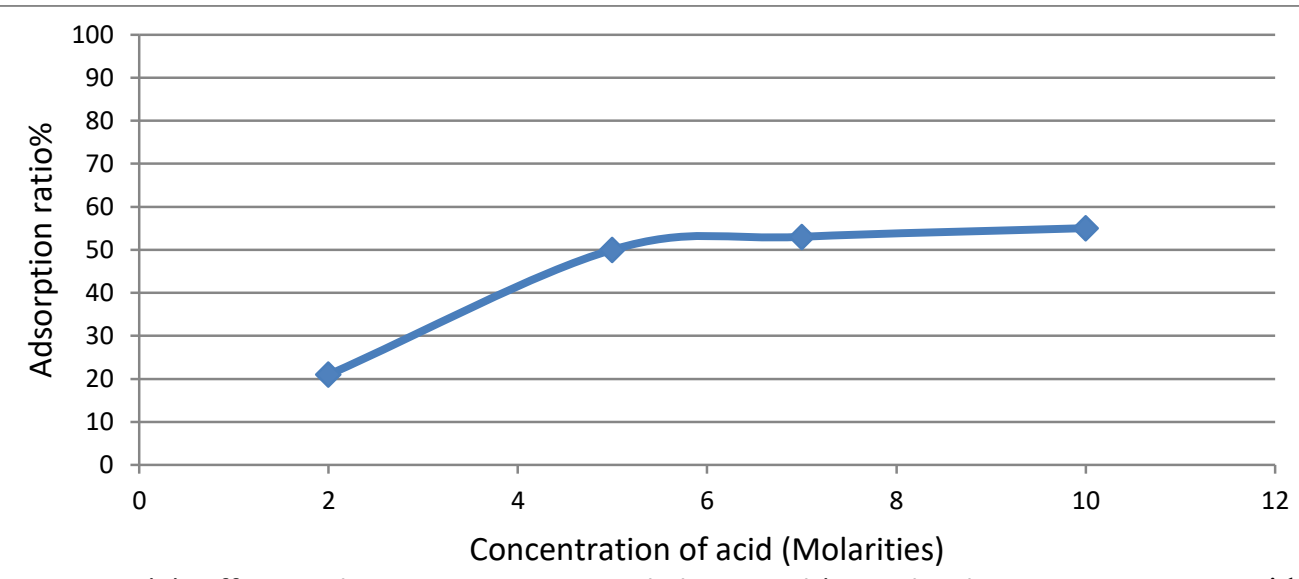

Fig.(1): Effect acid concentration on nickel removal (granular diameter $\leq 150 \mu \mathrm{m}$, acid to fly ash ratio $=10$, time $=3$ hours, temperature $=25^{\circ} \mathrm{C}$ ) 


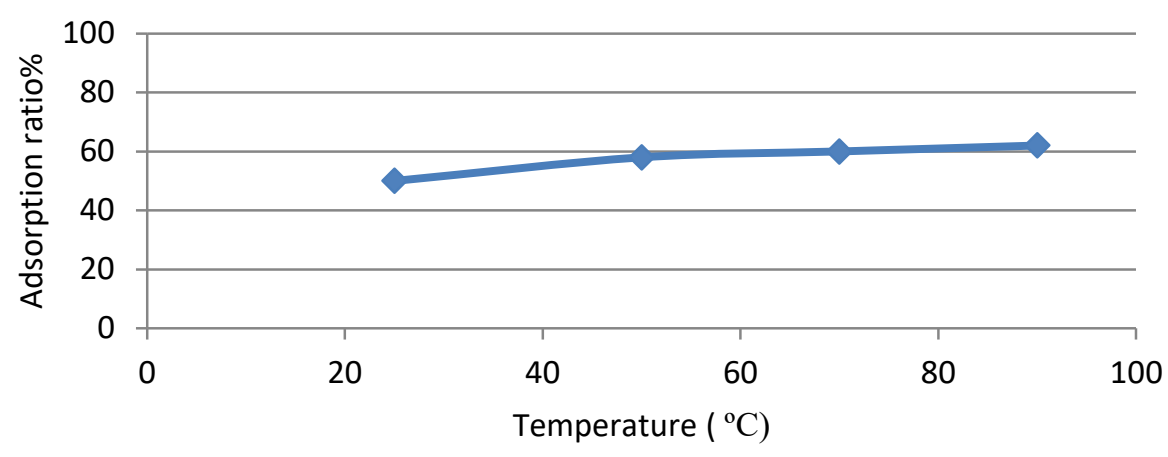

Fig. (2): Effect temperature on nickel removal (granular diameter $\leq 150 \mu \mathrm{m}$, acid to fly ash $=10$, acidic $=5$, time $=3$ hours)

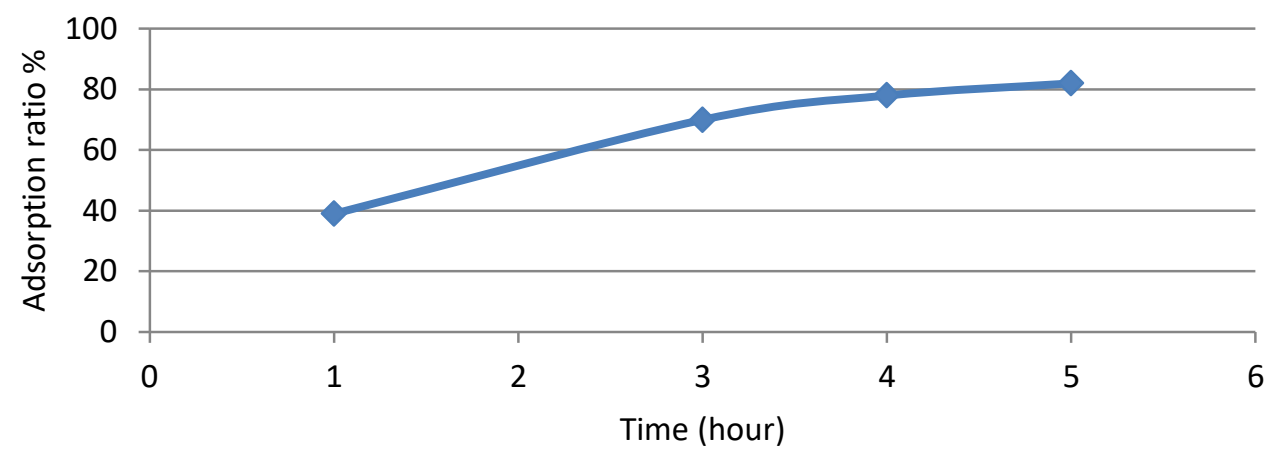

Fig.(3); Effecte of time on nickel removal ( granular $\leq 150 \mu \mathrm{m}$, acidic $=5$, temperature $=25^{\circ} \mathrm{C}$, acid to fly ash=10) 


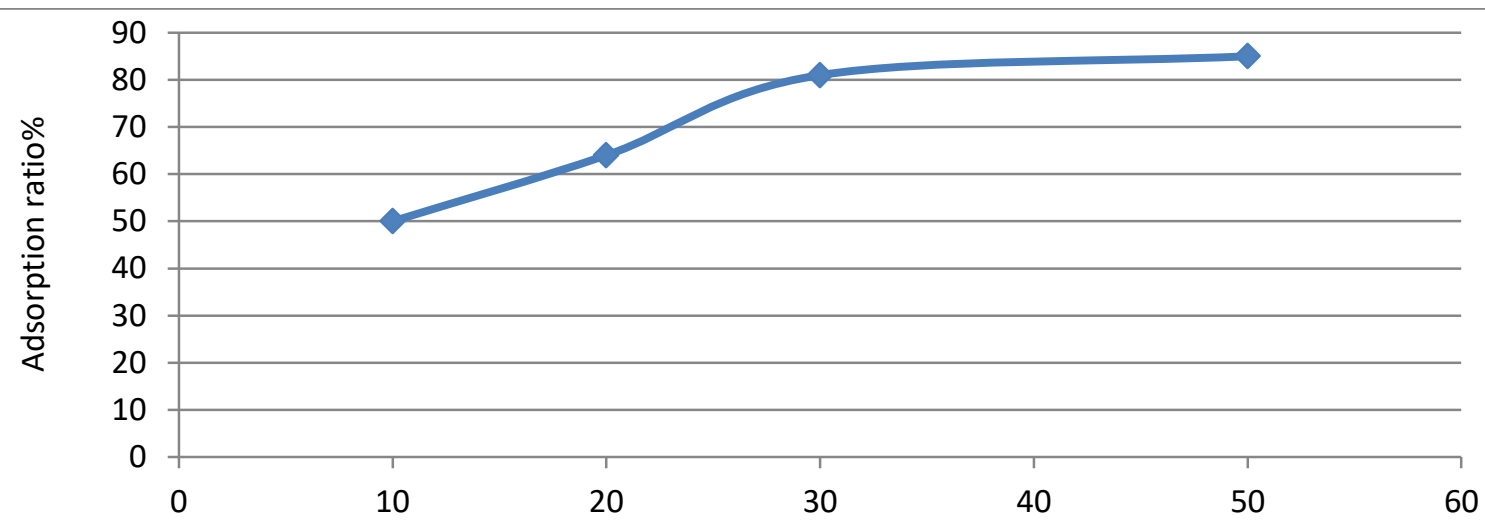

Acid to fly ash ratio

Fig (4): Effect of acid to fly ash ratio on nickel removal (granular diameter $\leq 150 \mu \mathrm{m}$, acidic $=5$, time $=3$ hours, temperature $=25^{\circ} \mathrm{C}$ )

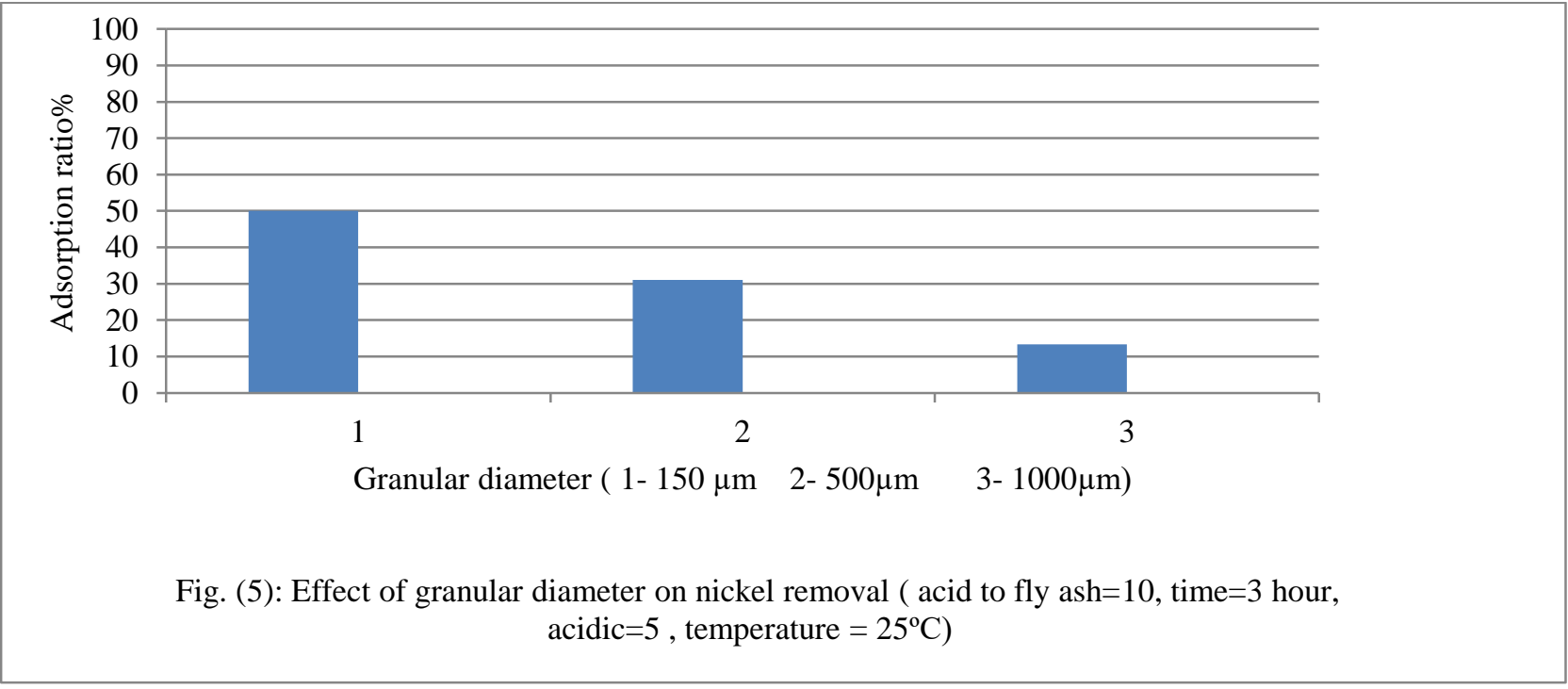

